\title{
COLONIAL AND TRADITIONAL URBAN SPACE IN JAVA: A MORPHOLOGICAL STUDY OF TEN CITIES
}

\author{
${ }^{1}$ SUNARYO, Rony Gunawan, ${ }^{2}$ SOEWARNO, Nindyo, ${ }^{3}$ Ikaputra, and ${ }^{4}$ SETIAWAN, Bakti \\ ${ }^{1}$ Department of Architecture, Faculty of Civil Engineering \& Planning, Petra Christian University, Surabaya; Student at \\ Doctoral Program, Department of Architecture and Planning, Faculty of Engineering, Gadjah Mada University, Yogyakarta \\ ${ }^{2,3,4}$ Department of Architecture and Planning, Faculty of Engineering, Gadjah Mada University, Yogyakarta \\ ${ }^{1}$ Email: ronygunawan@peter.petra.ac.id; rgsunaryo@gmail.com
}

\begin{abstract}
Most of morphological studies of cities in Java tended to place the elements of traditional urban space - such as Alunalun, Mosque, Palace and Market - as the main elements of city. Other elements such as the colonial urban space - Resident Office, Fort, Church, Park and so on - are often considered separately or placed as a complementary part. Through a morphological study by exploring ten cities in Java, I found both elements of traditional and colonial urban space were set in a unique and various pattern. There are some findings indicating that the elements of colonial urban space significantly influence the city structure as well as those of the traditional ones. Therefore, understanding the urban space form in Java should include and put elements of both of traditional and colonial urban space as an integral part.
\end{abstract}

Keywords: Colonial urban-space, traditional urban-space.

\section{INTRODUCTION}

Morphology of cities in Java where we live today is formed through series of long process with a variety of influencing factors. Some concepts that explain the influences of Buddhist, Hindu, Islam and European coloring process of the city formation in Java were generally accepted ${ }^{1}$. Legacy of European influence can be seen primarily through the physical artifacts of the Dutch colonial buildings spread in urban areas of Java. Through many in-depth studies, research on the influence of Europe on the world of Indonesian architecture can be said to have found the concepts that are fairly stable ${ }^{2}$. In contrast to the discipline of architecture - in which the scope is one building - in urban design or urban planning discipline - in which the scope is an area until a city, the stability of such a concept is found lacking. Explanations regarding the influence of the Dutch colonization to the urban space concept in which we live today, for example, are still quite limited and leave many questions.

\footnotetext{
${ }^{1}$ Some general publication resources used by urban researcher among others: Lombard with Nusa Jawa: Silang Budaya, Kajian Sejarah Terpadu (1996); Wiryomartono with Seni Bangunan dan Seni Binakota di Indonesia (1985), Santoso with Arsitektur-kota Jawa, Kosmos Kultur \& Kuasa (2008).

${ }^{2}$ Some recent studies focusing on Colonial Architecture among others: Handinoto with Arsitektur dan Kota-kota di Jawa pada Masa Kolonial (2010), and some articles in Nas (editor) with Masa Lalu dalam Masa Kini (2010) illustrated the interpretation which is almost equal to the development of colonial architecture in Java.
}

Dutch colonization process in Java lasted for several centuries, since their trading posts were built in the coastal cities to control infrastructure of transportation throughout Java. Although the influence of colonization looks so dominant in building a system of urban network in Java, it is the opposite in the scope of urban space. Colonization process does not remove the concepts of urban space forms that have already existed in Java. Alun-alun, for example, is the landmark of the city center derived from the precolonial traditions which still survives. Until now, the determination of the city center or the area of the old town mostly still refers to the position of the Alunalun $^{3}$. In contrast, there are some difficulties when we have to identify the elements of the colonial urban space, partly because of the absence of the concept of colonial urban space which can be applied in general. The main colonial elements forming urban space were different from one city to another, as well as characters formed later. In some cases, the colonial elements are mixed with traditional elements, so they become harder to determine whether the urban space formed is traditional urban space or colonial urban space. These facts lead us to a lot of questions, some of the most simple questions: Does the colonial period have role in the morphology of urban space in Java? What are the elements forming the colonial urban space? How does the process of interaction between

\footnotetext{
${ }^{3}$ Zero kilometer point in many cities in Java take the position of Alun-alun
} 
the elements of the colonial urban space and elements of traditional urban space?

This paper is the result of a brief literature review and observations on urban space in several cities in Java. The focus of this study is the morphology of urban space in the colonial period, especially in the early stages of formation of important structures in the city. The study does not attempt to find general concepts to answer the questions in the previous paragraph, but rather as an introduction to the understanding that further extensive and in-depth studies need to be done on the focus of the study.

\section{MORPHOLOGY AS A METHOD}

Morphology in the context of urban design is understood as a structuring/formation of an object or system. Meanwhile, the urban morphology as a structuring/formation of the city as object and system can be identified by structural, functional and visual (Zahnd, 1999). According to Weishaguna and Saodih $(-)$, the morphology of the city is an approach to understand the city as a collection of geometric configuration of buildings and artefacts with the configuration of units of a particular physical space which are products of socio-spatial change. Meanwhile, Widodo (2010) asserts that in urban analysis, morphology approach is appropriate to be used to identify the structural relationships among the artifacts of the city.

In general, the steps performed in the study were:

1. Physical artifact as an archive: tracing old map and satellite maps to identify the formation process of elements of urban space from beginning until present condition.

2. Synchronic and diachronic readings: a literature review to understand the factors that influence a city formation on different period.

3. Comprehensive scale: cross-disciplinary literature review of history of social, politics, culture, architecture and urban areas in order to obtain a comprehensive understanding of inter-scale, from buildings, an area until a city.

4. Verification: Field observations to feel the space is formed. Limited interviews were conducted with city historians, residents or the building manager to get the overall picture.

\section{LITERATURE REVIEW}

\section{Urban Space and Elements of Urban Form}

Krier (1975:15-16) simply described the concept of urban space as: "all types of spaces between buildings in towns and other Localities as urban space". He further added elements of street and square as the basic elements of urban space: "They are differentiated only by the dimensions of the walls which bound them and by the pattern of function and circulation which characterize them". Studies carried out in his book entitled the same, Urban Space (1979), aimed to realize the importance of understanding the urban space as a system. Nevertheless, Krier's analysis can not be separated from his weakness by developing typologies of urban space without a historical dimension (Kostof, 1992: 146). In spite of these weaknesses, Krier's effort is an important part of the many efforts from the architects, urban designers, and urban planners to understand the city through the elements of urban form ${ }^{4}$.

Broadbent (1990:4) concluded that the four basic principles that form the city are: the separation of the built-up area from surrounding countryside; the development of irrigation systems for intensive agriculture; the development of the power structure by which the irrigation systems, and other aspects of urban life could be controlled; and the development of craft-specialities to serve not only the needs of urban population but also as bases for trade. Meanwhile, to see the manifestation of these principles to the urban physical elements, Kostof's explanations can help us. Kostof (1992:72) described four kinds of specialized partition of the urban territory: the administrative district, where the ruling authority resides; the religious district; the district of business and commerce, and the residential component of the urban structure. Urban history in general noted that the first three points as the standard jurisdictional divisions of the public domain, and applied to the physical arrangement. Therefore, it can be concluded that the main elements forming urban space - which is public domain - will be representation of these three entities.

\section{Forming Elements of Java Urban Space}

City centers of Java in the pre-colonial period are often read through the elements of Alun-alun and important buildings in the surrounding including Kraton/Regency (The Palace) and Grand Mosque. The existence of Market element, despite its position

\footnotetext{
${ }^{4}$ Several similar efforts noted by Kostof (1992) are Stubben with Der Stadtebau-1924: Paul Zucker with Town and Square-1959: From the Agora to the Village Green. Michael Webb published a book with a similar topic with Zucker, A Historical Evolution: The City Square-1990 but the emphasis was on the analysis of the factors forming urban space such as political, social, cultural and ideological factors.
} 
apart from the first three elements, is the principle in the early formation of the city. The set of element is always a fixed composition and occupies important positions in the initial formation of the city. Some researchers mention Caturtunggal concept to explain the composition. Santoso's study of the Javanese cities in the pre-colonial period illustrates that this composition is a manifestation of the spatial concept that is based on the accepted principles for centuries in Java since the time of pre-historic settlement ${ }^{5}$. Considering these notions, it is no exaggeration to say that the set of Caturtunggal (Alun-alun, the Palace, Mosque and Markets) is a set of elements of traditional Java urban space.

A brief description of each element can be described as follows:

1. Keraton - Center of power, a keraton complex used as the residence of a king and royal family as well as the administrative center of the king (Ikaputra, 1995:31). The structure of Keraton is highly complex due to its highest hierarchical position in typology of Javanese residential class system $^{6}$. Furthermore, Santosa said (2000:90): "As a center of power, Keraton must have the capacity to express and maintain social order in which the Sultan occupied the top position." The complexity of the functions of the palace can be seen from amount of spaces that exist and its vastness, such as the Keraton of Sultan Hamengkubuwono in Yogyakarta which covers an area of 14,000 $\mathrm{m} 2$ wide. On areas outside the royal city, the center of power is manifested in the form of Regents Residence often called Kabupaten or Kadipaten. Although it is not as complex as Keraton, Kabupaten remains the most complex buildings in the territory.

2. Alun-alun, part of Keraton complex. The existence of Keraton is characterized by the presence of Alun-alun in front of it and vice versa. Alunalun shape is a large rectangle square - for example Alun-Alun Yogyakarta, one of the largest Alun-alun in Java which has 275 length and 275 meter wide - with the existence of a banyan tree in the center and circumference as a symbol of the harmony of the microcosmos and the macrocosmos afforded by the king (Pigeaud, 1940 in Santoso, 2008). Activities that take place

\footnotetext{
${ }^{5}$ Santoso (2008: 187) conveyed that principle of microcosmicdualistic and microcosmic-hierarchical is the foundation of civilization of Java, from which the concepts of space and the art of building structure are derived.

${ }^{6}$ Through in-depth studies about Javanese House and its meaning, Santosa - Omah, Membaca Makna Rumah Jawa (2000) presented four cases of Javanese house from the simplest to the most complex: Kraton.
}

in Alun-alun are generally associated with Keraton and Great Mosque at its west side. Santoso (2008) summed up the square function in pre-colonial period as follows: a symbol of the legitimacy of the sovereignty of the king over the people; the course of all religious activities and the kingdom; a showcase of military power

3. Mosque and Kauman, located on the west side of Alun-alun $^{7}$, the city's Great Mosque. Large-scale religious activities of Garebeg (Maulud, Syawal and Gede) three times a year took place with the involvement of elements of the Great Mosque, Keraton and Alun-alun. This fact confirms the existence of unity between religion and the ruler at that time. Meanwhile, Kauman itself is a residential area such as the physical character of Kampung in general outside of the palace. The difference is the atmosphere that characterizes the Islamic religious activities in that Kampung. The existence of Kauman and Mosque in Yogyakarta case can not be separated from Keraton because the perpetrators were religious officials appointed by Sultan (Ikaputra, 1995: 36).

4. Market, a specified location for trading activity. The central function of the market activity is the social and economic interactions in a single event (Wiryomartono, 1985). Furthermore, market position in Java is not oriented to the town square as the concept of commercial space of medieval European cities; otherwise, its position tends to separate from the three previous elements. Javanese concept of space considers market as a manifestation of mundane activities (Wiryomartono, 1985:58) and the concept that the north side of city is a profane space (Santoso, 2008:177) simply describes the position of the market which is always far away on the north side of Alun-alun area.

The topic related to the study of urban space in Indonesia - or at least close to the scale of urban space, especially in cities in Java has received wide attention from many researchers, especially in the disciplines of history, architecture and urban planning. As far as I can observe, one focus that is mostly attracting attention from the researchers is precolonial period, which was later found Caturtunggal concept as a set of traditional elements of the central Javanese urban space ${ }^{8}$. Nevertheless, there are some studies that were extended up to the colonial period.

\footnotetext{
${ }^{7}$ Salatiga city is an anomaly because of the existence of the Great Mosque and Kauman located far apart with element of Alun-alun and Kabupaten

${ }^{8}$ Among others: Suryanto \& Indanoe (1987) - Kotagede, A Traditional Settlement; Santoso (2008) - Arsitektur -kota Jawa, Kosmos, Kultur \& Kuasa.
} 
In general they are explanations of factors that influence the formation of city structure and pattern?. The study from Sandi Siregar is one of the most indepth studies departing from analysis of element and form of the city to illustrate the concept of urbanity and architectural identity of Indonesia ${ }^{10}$. Some of these studies provide an understanding that the elements formed by colonial play an important role in the evolution of Java urban spaces we inhabit today.

\section{Colonial City Principles}

The most detail town planning principles of European colonial can be seen in the Law of the Indies in 1573, that became the benchmark of Spanish colonies in forming the structure of their colony cities (Nuttal, 1921, 1922 in Broadbent, 1990: 42-48). Some rules discussing the placement of the main elements of the city, among others, stated: The placement of the main plaza as the starting point of the city (Ordinance 112 in Kostof, 1992:124); the main church as the central building - as part of the spread of religion in the colony - was placed in the main plaza; the placement of public buildings such as the royal council, city hall, arsenal, hospital, merchants is placed around the main plaza without compromising the primacy of the church. Even though it is complete and frequently used in many cities of Spain and Portugal colony, the application of Law of the Indies by the Dutch colony is still questions and doubts. One of these doubts is the fact of the different orientation of colonization ${ }^{11}-$ the Spanish has a mission to civilize the colonies, while the Dutch is more likely to trade missions - therefore, the city established by the Dutch acts more like trading post function (Broadbent, 1990: 47).

Records that might be closer to the context of the Dutch colony were a note on the concepts of the ideal city from Simon Stevin (1548-1620), a Quartermaster-General at the time of Prince Maurice of Nassau. Stevin issued ideal city concepts, among others parameters and the main elements of the city ${ }^{12}$.

\footnotetext{
${ }^{9}$ Among others: Wiryomartono (1985)- Seni Bangunan dan Seni Binakota di Indonesia; Handinoto (1996) Perkembangan Kota dan Arsitektur Kolonial Belanda di Surabaya (1870-1940); Handinoto (2010) - Arsitektur dan Kota-kota di Jawa pada Masa Kolonial, Santoso (2009)-The Fifth Layer of Jakarta

${ }^{10}$ Bandung, the Architecture of a City in Development, is a doctoral thesis of Sandi Aminudin Siregar at Katholieke Universiteit Leuven, Belgium in 1990.

${ }^{11}$ Dutch policy clearly limited the mixing of the elements of European culture and Java with a particular motivation. Lombard (1996: 94).

${ }^{12}$ Research by van den Heufel (2005) was a complete study to discuss Simon Stevin heritage in the field of Architecture, Planning and Civil City: 'De Huysbou' A reconstruction of an unfinished
}

Some urban morphological studies refer the model of fortress (Sterctenbouwing) and the concept of ideal city from Stevin as a basis for designing Stevin VOC fortress and fortress city in the early colonial period ${ }^{13}$.

Regarding the shape of a city, Stevin wrote: "The four-sided rectangle on a flat level piece of ground is in my opinion the most convenient shape for towns, in order that they may contain suitable rectangular blocks, such as plots, houses, gardens, markets and squares, which do not fit in another shape; because pentagonal and polygonal towns, although they can be drawn in a circle, with a wellordered market in the centre and streets from there to the bastions, all with a likesided form, yet many houses, blocks and plots become lopsided and broader at one end than at the other..."

Regarding the main elements of the city, Stevin's concept put Major Market - no less than six markets that he suggested - as the center of the city followed by Churches, Residence of the Prince, City Hall, Jail and House of Correction. The placement of these elements is placed in the center of the city, except that the Residence of Prince, due consideration to the balance between control and sense of security of urban dwellers - especially foreign merchants - not placed in the center of town but in the city wall (Heufel, 2005: 353-361)

In further developments since the second half of 18th century, fortress city pattern is becoming obsolete. Handinoto (2010: 226-230, 430-431) illustrated that from the typology of cities in the period of the early 18th century until the late 19th century there were two distinct characters, namely the Old Dutch East Indies City and the New Dutch East Indies City. The pattern of the Old City established earlier has two city centers, the native city center - with Alun-alun and Kabupaten as the main elements - and the colonial city center - with the main elements of the Residence of Resident or Assistant Resident. Meanwhile, the pattern of the New City was formed later with one city center characterized by the merging of indigenous and colonial administrative center in one location, at Alun-alun ${ }^{14}$.

The urban pattern formed after Decentralization Act in the early 20th century was the creation of a new town center trying to appear modern and away from the traditional image of Javanese. The new elements like Municipalities Office and also the great

Treatise on architecture, town planning and civil engineering by Simon Stevin

13 Among other studies of Kwanda (2010:23) about Profil Kawasan Cagar Budaya Surabaya

${ }^{14}$ Gill disertation (1995) proposed the theory that the structure of Java greatly was influenced by the system of administration policies, changes in the system affected the structure of the form. 
parks were built on the site away from the old city center. Handinoto (2010) described one of the backgrounds of this new urban development is the desire to demonstrate more the existence of colonial power in the colonies ${ }^{15}$.

\section{Distinguishing Aspects}

Kostof (1992:73) proposed a classification based on topography and dimensions of time as an aspect that distinguishes one city from another ${ }^{16}$. Similar classifications are also used by many researchers of cities in Java. There are aspects of geography and time period. Based on geographical character, researchers divided the cities in Java into two categories (Nas, 1986; Zahnd; 2008; Handinoto, 2010; Santoso, 2008):

1. Coastal cities which are located in the north of Java Island, on the basis of trade and culture that tends to be egalitarian.

2. Inland cities which are located in the center of Java Island, on the basis of agriculture and culture that tends to be feudal.

Kostof stated (1992: 78) that the analysis of urban form must consider the specific conditions - the context of cultural, political and social change; therefore, the dimension of time becomes significant. In general, Nas (1986: 5) divided the transformation of the Indonesian cities into four stages: the early Indonesian town; the Indische town; the colonial town; the modern town. Although this classification does not represent exactly the facts in each city because it could be for example the context of political change in one area that is more advanced than others - but in general it can be used as a tool of analysis ${ }^{17}$.

\section{FINDINGS AND DISCUSSION}

\section{Main Elements of Colonial Space}

Although the interpretation of the colonial elements can be interpreted by elements built by the

\footnotetext{
${ }^{15}$ Decentralization arose because of the rapid urbanization in the early 20th century, a dense urban population raised awareness that the city needed the local board and did not depend on the Batavia Government Center. It should be noted long time before, liberalization factor in the Netherlands, the opening of the Suez Canal was a global factor affecting economic growth in cities in Java.

${ }^{16}$ In the case of Western European cities, based on topographic, Kostof distinguished between the cities of the hilltop to the valley town. Meanwhile, for the aspect of time he distinguished between pre-industrial cities and the cities of the modern industry.

${ }^{17}$ The political, social and cultural unity can be said to occur after the 20th century, before that time the political, social and cultural changes in each city were not running equally.
}

colonial party, in this study the terminology are limited to the elements that functioned primarily for direct interests of the colonial authorities ${ }^{18}$. The study results found that the following elements can be said to always appear in the center of the city and has a strong character in the formation of urban space. Some of the main elements in the city that can be used to identify the colonial urban space are as follows:

1. Fort: element of the colonial that gives, for the first time, color to the structure of city in Java can be said generally through its fortress. In the VOC period (before the 19th century) the fort was built for the purpose of defense, and the administrative center of government and symbols of economic and political domination of the Dutch colony in the colony (Gill, 1995 in Marihandono).

2. Resident's Residence and Office: Residents in the period before the 20th century were the officials of Dutch colonial government under the Minister of Domestic Affairs of Colonies Region (Directeur Dept. Van Binnenland Bestuur). The territory covers the Residensi, an area of approximately a district in the present. Resident's residence or office is the administrative and authority of the Dutch colonial government on the area of Residensi. On a smaller area under Residensi, named Afdeling, the highest official is Assistant Resident ${ }^{19}$.

3. Church: Although the principles of Law of the Indes and Stevin's concept assert the primacy of the Church element, there was very limited sources that explain the principles of Church placement after the fortress city in Java. Some notes from Lombard and church history literature illustrate that the position of religion in the Dutch colonization did not stand out as it appeared on the Spanish colonization. The Dutch, since the beginning, did not include the special role of religion in their mission, and even tended to limit the interference of religion in the administration of the colony. Restructuring of the churches as a new institution began only after $1815^{20}$. Through the study of literature related to the history of the

\footnotetext{
18 This is to clarify why the elements such as Mosques, and Kabupaten built by colonial on several cities are not included in the category of colonial element, or vice versa Rastenburg fortress built by Sultan Hamengkubuwono is not included in the category of traditional elements.

${ }^{19}$ Handinoto (1996) referring to Cobban (1970) described the structure of the Dutch East Indies before the twentieth century, it appears there are two governance structures: the Dutch and the Natives

${ }^{20}$ Among others, gathering all the Protestant congregation across the archipelago in Protestansche De Kerk in Oost Indie and forming the Assembly of the Church under the Ministry of Trade and Regional Development of Colonies and King William Church (now Immanuel) as its center in Batavia in 1835-1839.
} 
church in $\mathrm{Java}^{21}$, we can conclude the role of Protestant missions (Catholic later) was limited to humanitarian issues such as health and education.

4. Parks: The role of parks in the colonial period rarely discussed in publication, but the fact that they were present in key locations such as in front of Church, Resident's Residence or Main Intersection in the city showed their significance in the formation of urban space structure. Handinoto (1996:81) based on the case of Surabaya illustrated that the development for open space before the phase of Gemeente came from private initiative. However, more studies need to be done looking at the fact that there were major parks in the colonial city center before the 19th century - in which private role was not dominant as it was in the 20th century - among other cases, Kediri, Pekalongan, Tegal and Salatiga.

5. Stations \& Railways: Following the Great Post Road that connected landline of Java in 1810, the discourse to the railway came in 1840. The first network that connected Semarang-Kedungjati was completed in 1871. After the development of a comprehensive network which was intensively carried out, by the year 1894, recorded by Lombard (1996:140), the first line was completed across Java. Network construction was continued until the 1920's, called by many notes that the rail network was the most complete network and the densest in Asia at that time. The same as the pattern in Europe, the placement of the station as a meeting with the rail network and the highways was located in the city center (Handinoto, 2010:333). These facts are sufficient to show the significance of the Station as an element affecting the structure of Java urban space.

6. Telecommunications and Trade Office: Immediately after the economic liberalization in the Netherlands after 1870 , the opportunity for private to conduct business in the colony was open widely. These conditions led to the needs of business \& trade offices on a large scale ${ }^{22}$. With the increasing economic transactions of the city, the needs for communication connectivity between regions in the colonies as well as the colonies to the Netherlands were increasing, so

\footnotetext{
${ }^{21}$ Regarding the relations with the church in the Dutch colonies, it can be found at Lombard (1996:97-102) part Peran Komunitas Kristen; Sejarah Gereja di Indonesia (2008, archives of GPIB Kediri); and book 75 tahun Jemaat Kristen Jawa Sawokembar Gondokusuman Yogyakarta (Majelis GKJ Sawokembar Gondokosuman Yogyakarta, 1988)

${ }^{22}$ Some of big trade offices in Java, among others De Javasche Bank, Nederland Handels Mij, Ned. Indische Escompto Mij, Ned. Indische Handelsbank.
}

that the telecommunications office buildings such as postal, telephone and telegraph appeared.

\section{Set of Elements of the Early Colonial: Fortress City}

The early colonial period in the 17 th century was marked by the establishment of the fort in areas that were considered strategic to the economy by the $\mathrm{VOC}^{23}$. Departing from the initial function as a symbol of existence, it evolved into a center of government and administration activities of the territory of these business entities (Marihandono, 2007). Establishment of the fort or citadel, especially in the case of coastal cities, aimed at securing a trading post and community interests of internal security. The fort can be considered as a small town, so the set of existing colonial elements gathered in the fort.

After the VOC took stronger political position in the city, other elements grew around the castle like: Resident's Residence, Dutch Settlement, Churches, Parks, Prisons and Markets. Placement of the elements in this period is set apart from the traditional set of elements that have been there before, namely: Kabupaten/Kadipaten-Alun-alun-Mosque-Market.

The sense of the word 'separate' here describes separation by distance, as it can be seen in the case of Semarang, Salatiga, Pekalongan and Kediri. Separation that occurs between elements of colonial and traditional elements in the case of Pekalongan and Kediri is increasingly punctuated with elements of the river as a barrier.

Separation of the elements of traditional and colonial urban space, among others, was due to the relation that exists between local authorities (Duke / Regent) and colonial (VOC officials) at the time. In the early colonial period the relations were limited to trade affairs and there was no intention from the Dutch to meddle too much in the native political affairs $^{24}$. This condition is much different from the style of the Spanish colonies, which demolished Tenochtitlan elements of traditional urban space since the beginning and replaced it with Spanish elements ${ }^{25}$.

\footnotetext{
${ }^{23}$ Handinoto (2010:429) illustrated the establishment of the VOC fortress on the banks of the river in Jepara city that serves as a storehouse of the earth before it was brought to Europe.

${ }^{24}$ Lombard (1996:106) citing Schrieke illustrates the difference in perception between the Governor-General Van Imhoff and High Commissioner of Netherland in the year 1802 as a different perception of how the position of Regents to the Governor-General in Batavia

${ }^{25}$ Broadbent (1990:42-43) described the Laws of the Indes as the principles used in developing the city in the Spanish colonies, while Lombard (1996: 94-95) explained the different background of VOC policy that tended to give priority to trade with the Spanish mission of civilizing people in the colony.
} 

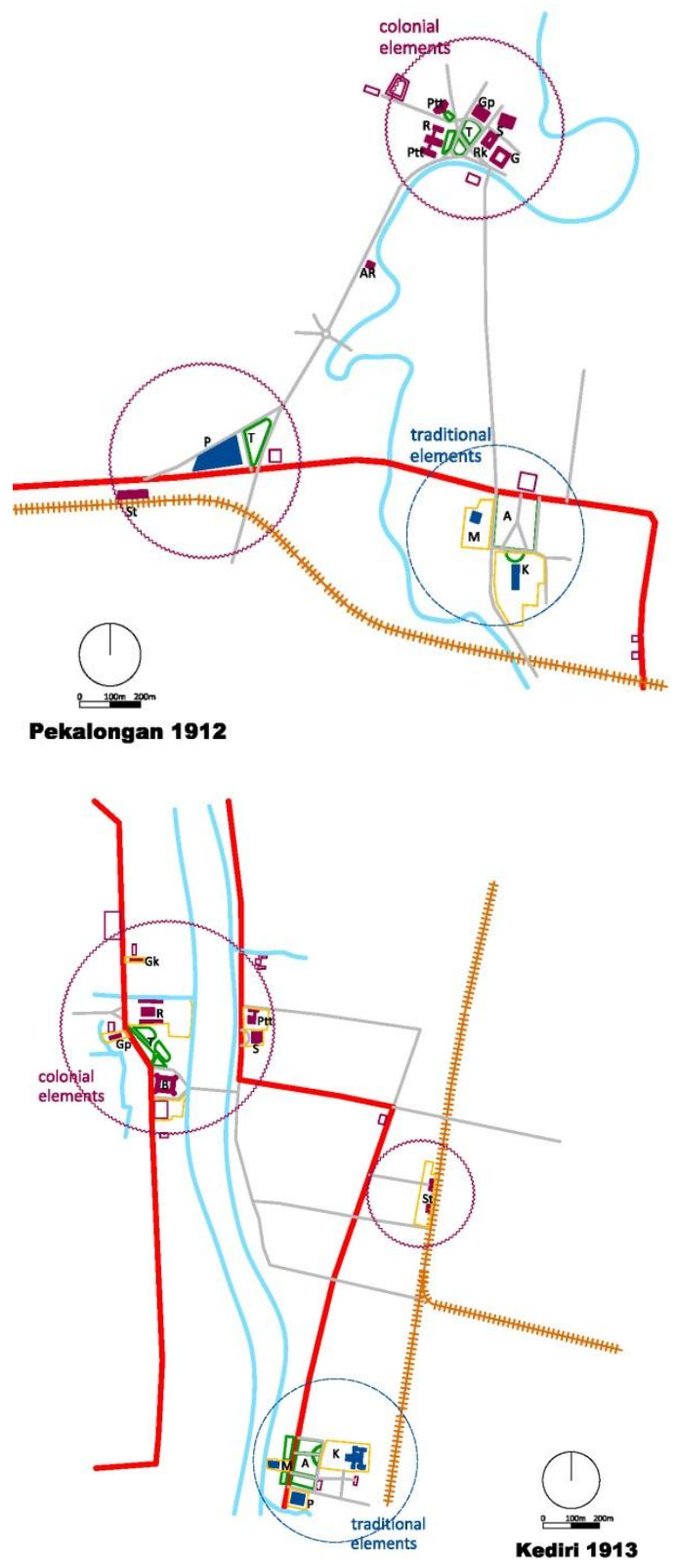

Source: Analysis from Map and Field work in 2011-2012

Figure 1. Set of colonial and traditional elements that stands apart at Pekalongan (left) and Kediri (right)

Case of considerable interest is found in the case of Salatiga. The separation that occurs is not limited to the elements of colonial and traditional elements, but even each element stands apart without following the general pattern. The set of traditional elements which are, in general, caturgatra pattern stands apart: the Great Mosque and Kauman with Alun-alun and Kabupaten - in which in general pattern become an integral part-stand apart in distance. Meanwhile, the set of colonial elements that form an integral set as we saw in Kediri and Pekalongan, can not be seen in Salatiga; elements of the Resident Assistant's Residence - Park - Church stand apart from the fortress and prison.

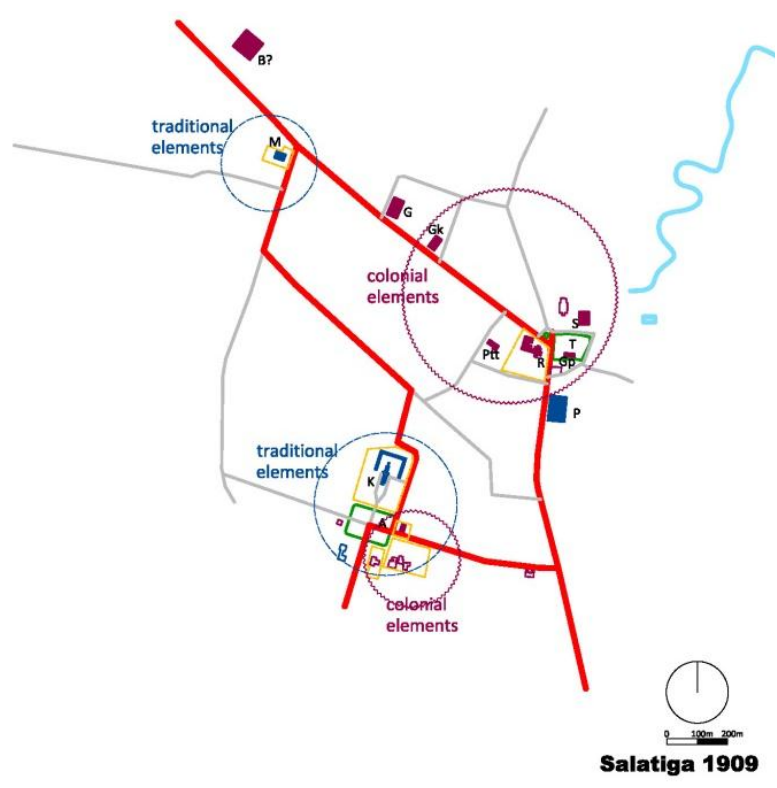

\begin{tabular}{|c|c|c|}
\hline LEGENDA & $\begin{array}{l}\text { B - Benteng } \\
\text { R - Rumah Residen } \\
\text { Rk - Kantor Residen } \\
\text { AR - Asisten Residen }\end{array}$ & $\begin{array}{l}\text { S - Societeit } \\
\text { Ptt - Pos, Telepon, Telegraf } \\
\text { St - Stasiun } \\
\text { D - Kantor Dagang }\end{array}$ \\
\hline \multirow{3}{*}{$\begin{array}{l}\text { K - Keraton/Kabupaten } \\
\text { A - Alun-alun } \\
\text { M- Masjid - Kauman } \\
\text { P - Pasar }\end{array}$} & \multirow{3}{*}{$\begin{array}{l}\text { G - Penjara } \\
\text { T-Taman } \\
\text { Gp - Gereja Protestan } \\
\text { Gk - Gereja Katolik }\end{array}$} & Pagar/Batas Kawasan \\
\hline & & Jalan Pos/ Jalan Raya Pos \\
\hline & & Rel Kereta \\
\hline
\end{tabular}

Source: Analysis from Map and Field work at 2011-2012

Figure 2. Set of traditional and colonial elements that is far from each other and does not follow general pattern in Salatiga

\section{Set of Elements of the Middle Colonial: Central Administration Complex}

The composition in which the structures of colonial and traditional sets of elements stand adjacent can be found in the case of Yogyakarta and Surakarta. Comparing the scale of its range, Caturtunggal set of element (Keraton, Alun-alun and Great Mosque) is more dominantly visible than colonial set of elements that are set right on its northern side. Set of colonial elements in both cities - although the cities were established at different periods - almost the same as the set of elements in Kediri and Pekalongan: Fortress, Resident's Residence ${ }^{26}$, the Church and the Dutch Settlement. In this period there is no separation of the components of the Market, two sets of elements appear to use the same market; a position in both cities is equally close to the set of colonial elements.

\footnotetext{
${ }^{26}$ Placement Home Minister (herein after House Resident) in front of the Fort Rustenburg (later named Vredeburg), Yogyakarta was described by Marihandono (2007:3) as part of politics from Daendels to strengthen the European position in the central region of the Javanese Royal Cities (Vorstenlanden)
} 


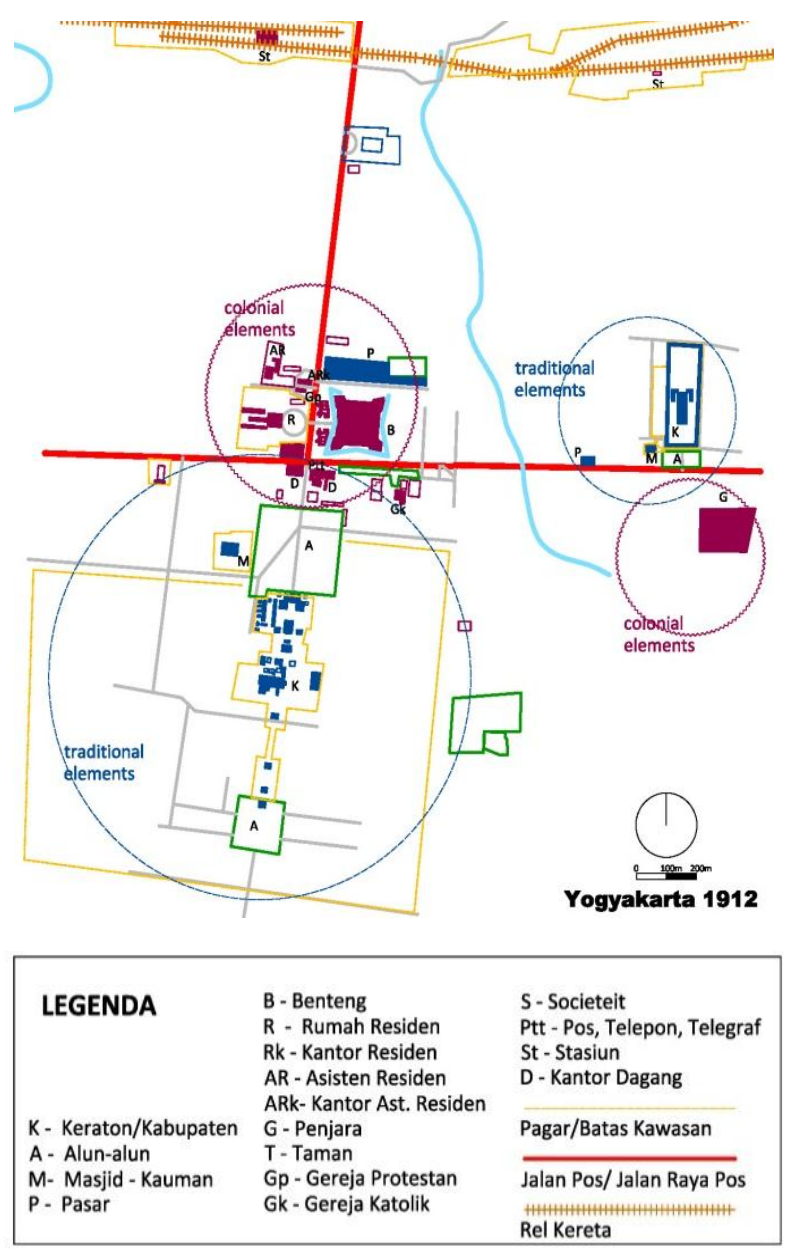

Source: Analysis from Map and Field work in 2011-2012

Figure 3. Set of traditional authority element that is adjacent with set of colonial authority

Meanwhile, in the case of Magelang, similar conditions prevail. Buildings of Kabupaten, Resident's Residence (both in the 19th century) and Gemeente Huis (after the 20th century) are in one administration building complex. Differences between Surakarta and Yogyakarta were oriented to the placement of the church that was oriented to Alunalun, and the castle that was replaced by Prison elements.

\section{Indis Element Set: Alun-alun as the center}

Some cities use the elements of Alun-alun as the center of the orientation of the main elements, both traditional and colonial. Purworejo, former the capital of Karesidenan Bagelen which became the Regency of Puworejo later, is the most obvious example. Alunalun of Purworejo became the center of the placement orientation of main elements: Kabupaten, Great Mosque, Assistant Resident's Residence, Church, Prison, Post Office, Hospital, and even the Station.
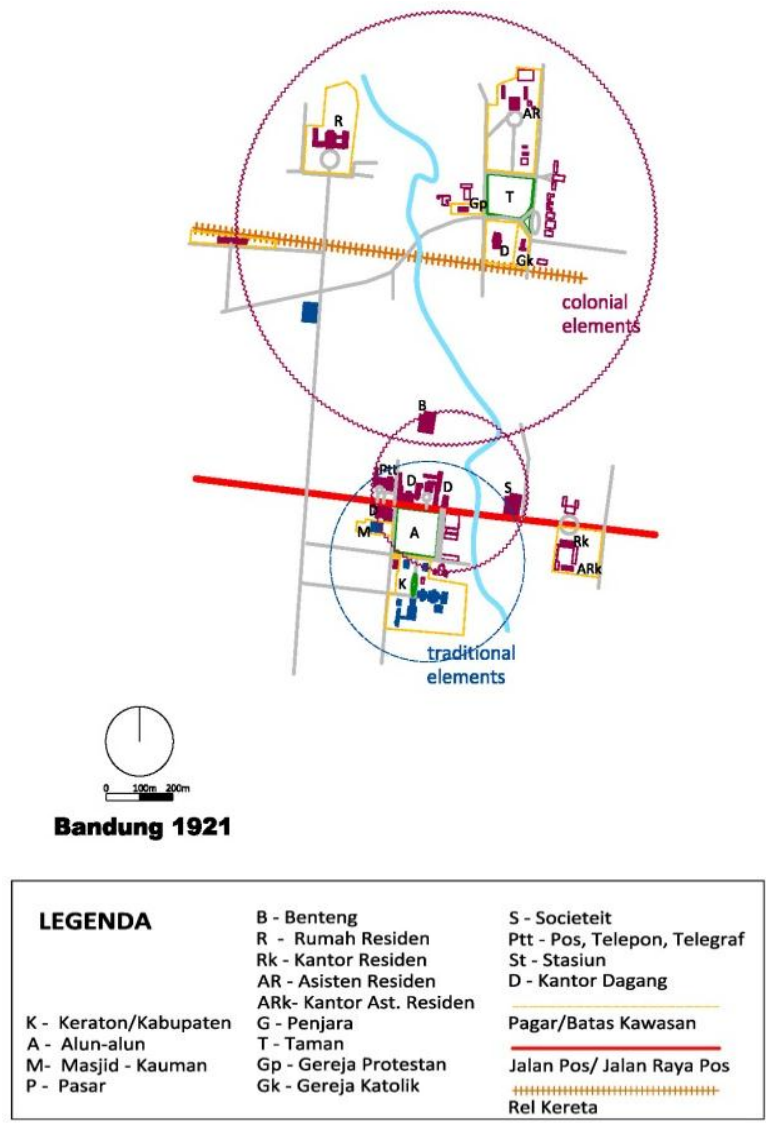

Source: Analysis from Map and Field work at 2011-2012

Figure 4. Set of traditional element which is mixed with set of colonial element at Bandung

City of Bandung at the time of initial set up was a case where the set of elements of the colonial government set was mixed with traditional elements. Alun-alun became the center orientation of Kabupaten, Great Mosque and the Resident Assistant's Residence $^{27}$. Gill (1995) advanced the thesis of this pattern as the pattern of the New Dutch East Indies City arising from the influence of colonial policy of indirect rule system $^{28}$. Meanwhile, further to the political aspect, in the opinion of Van den Bosch in 1833 (in Lombard, 1996:106), he described the background and motivation of the Dutch to choose to maintain cooperation with the native rulers was for the stability and profitability of the Dutch economy.

\footnotetext{
${ }^{27}$ Analysis from Siregar (1990) based on Bandung map in 1822 showed the position of Assistant Resident's Residence just in the north of Alun-alun. In further development, the Dutch central government moved further to the north, the maps after 1900 showed a model set of elements of the colonial government around Pieters Park, or City Hall now.

${ }^{28}$ Regarding indirect rule termed by Lombard (1996:106-107) with "an iron fist in a velvet glove", a review of the background of this dual conception of the administration was described by a fairly complete.
} 
Meanwhile, Nas (1986:7) assumed the composition was an example of influence from the burgeoning Indies culture at that time ${ }^{29}$.

\section{Set Element of the End Colonial: Central Econo- mics and Center for Modern City}

The 19th century can be said to be the influential period on the change of economic and administration system in the colonies, especially in Java. Some influential events include:

1. Bankruptcy of the VOC and the shift of power to the Government of the Dutch East Indies colony in 1800

2. The Great Post Road infrastructure was completed in 1810

3. Enforcement Cultuurestelsel in 1830, ended in 1870 with the shift in the concept of liberal economy.

4. Rail transit system across Java in the late $19^{\text {th }}$ century

5. The rapid development of telegraph systems in the second half of the 19th century

6. Telephone network in the early 20th century

7. Implementation of the Decentralization Acts during the first three decades of the 20th century.

Record of the events above simply shows that the infrastructure of cities in Java was prepared by the Dutch to support the resilient economy system of the region. This fact explains how the main elements of the 19th-and-20th-century cities were formed. The buildings that are part of the main elements of the city at that time include: the Post and Telegraph Offices, Stations, Office of the Private Trade. The main elements of the new city form a set of elements that are inevitably affected the structure of the city. In general, the position of the main elements of this economy is contiguous and forms a set of specific composition. Look at the influential parties, it can be easily concluded that the economic element of this set is a set of colonial elements.

The unique part of the set of elements of the colonial economy is on the scale and variety of its placement. Elements such as the Post and Telegraph Office, Office of Trade are generally close together, and some even form a set of colonial urban space that is strong enough as in Pekalongan, Tegal, Semarang, Yogyakarta and Surakarta. Meanwhile, elements of the colonial economy in the city of Bandung and Magelang actually put themselves to join the traditional set of elements, oriented to Alun-alun.

\footnotetext{
${ }^{29}$ A brief study of Indis Culture can be read from Cribb (2003) 'Indisch' Identity and Decolonization, or a in-depth study from Soekiman (2011), with his book titled Kebudayaan Indis dan Gaya Hidup Masyarakat Pendukungnya di Jawa, which was a publication version from his disertation in 1996.
}

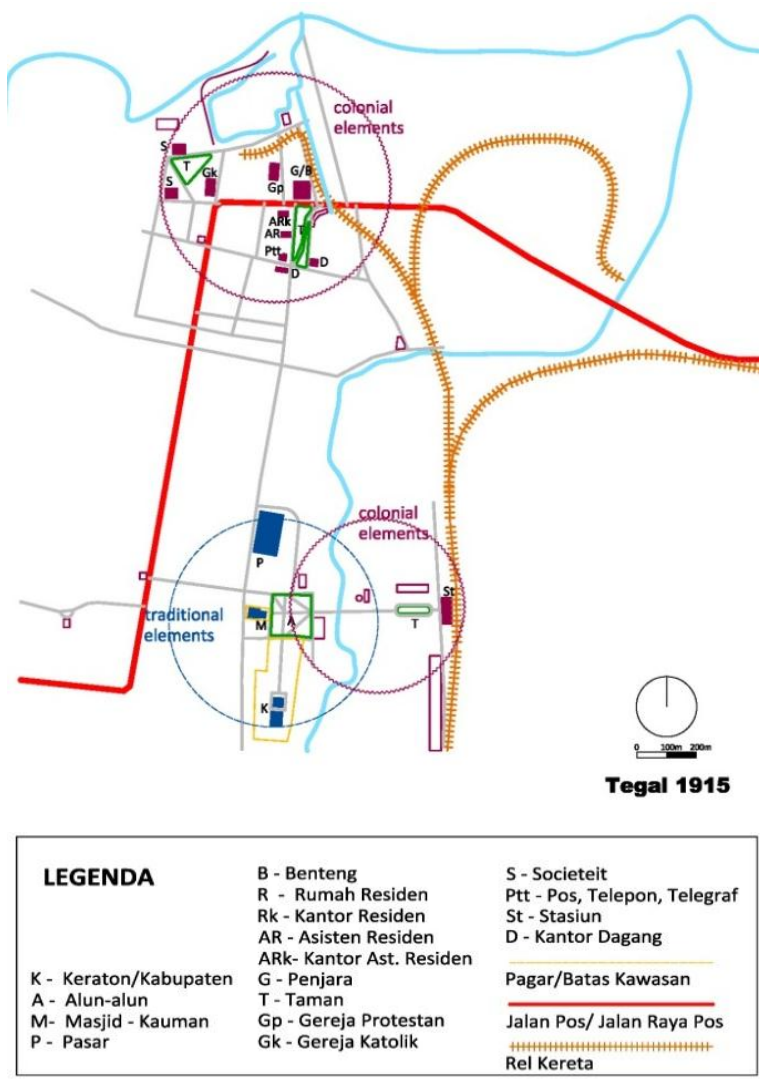

Source: Analysis from Map and Field work in 2011-2012

Figure 5. Set of station element that is oriented at set of traditional element in Tegal

Placement of elements on the station is generally oriented or at least adjacent to the Main Market of the City and is located apart from the city center. Strong character of urban space is rarely formed of this composition as in the case of Pekalongan, Kediri, Bandung and Magelang. Placement of the station as a city landmark can be seen in the case of Tawang Station in Semarang which together with a polder in front of it forms the strong character of urban space in the Semarang Old City District. Meanwhile, in Purworejo we saw the laying of the station in the city center, adjacent to the Kabupaten, but not forming a strong character of urban space. Tegal case is an example of the placement of the station elements which are integrated with elements of Parks, Office of the Bureau and Caturtunggal, the set of traditional elements. Station placement in this position is probably due to a main line and the nearest rail line to the main market, but the design of the station of Pont to combine elements of the set square is still a unique composition that is rarely found in cities in Java ${ }^{30}$.

\footnotetext{
${ }^{30}$ Among others Malang, Probolinggo dan Jakarta which have similar pattern
} 
Local and international transportation infrastructure which were improved and the freedom to try brought by liberalism in the colony have driven the rapid rate of urbanization. Urban population increased rapidly not only from the natives, but also from Europeans who were trying their luck in the land that promised a lot of opportunity at that time. Complexity of the existing urban drove awareness that the city needed to be managed professionally by a local institution. Decentralization Act in the early 1900's brought the cities in Java to have special autonomous local administrations to manage the problems of the city. From the aspect of governance structures, new structures emerge such as the Mayor, Council and the People's Court. Elements such as the Mayor's Reidence, the House of Representatives and the Court are the last colonial element set. Placement set the last element is no longer bundled with the initial set of traditional elements or Indis set, but occupies new territory in the city. Set elements of Mayor'sOfficePark- Church-City Council of the church and the court became a separate new town center which stands apart with the centers of the old city. Complete set of elements can be seen in Bandung, while other cities like Semarang are modified.

\section{CONCLUSIONS}

Looking at the findings of fact and discussion it can be concluded that:

1. Colonial period plays an important role in the morphology of urban space in Java. The changing context of social, political and cultural rights caused by the colonial authorities-either consciously or not-was significant in influencing the shape of the Java urban space we live in today.

2. Forming elements of urban space in the colonial period varies, depending on the context of time (change of political system, economy and technology) and geography (local potential and the position of the constellation of regional economies).

3. In general, Java urban space has similar main elements; the variation - if there were - comes from the composition and placement of the colonial elements.

4. Composition of colonial elements set is dynamic and there is no single pattern that can be applied to all cities. Instead, the set composition of traditional elements namely the Caturtunggal was static, fixed and found in all cities, except for the case of Salatiga. This fact suggests the role of the traditional elements of the composition of the set is a fixed element in the central Java urban space, while the role of the composition of colonial set of elements that do not fix gives diversity in each city of Java, so that each of the cities of Java is a unique entity.

5. Referring to the morphological phase of urban space that happens, the use of periodization by Nas - Colonial Cities and Towns Indies - to read the Java urban space concept in the colonial period becomes less representative to the reality. Periodization of the proposed classification is based on the concept of a dominant force at the time: The period of urban space as a space power; period of urban space as the space for administrative center; period of urban space as an economic space and the period of existence of urban space as a space of modernity.

Some researchers using the urban morphology approach stated the factor that the structure of Java urban space which was uncertain at the beginning of its formation was the cause of the weakness of the conception of urbanity of our cities today ${ }^{31}$. Cities in the pre-colonial Java are a collection of villages that each has different value system, so the city is not a unity of political and cultural entity ${ }^{32}$. This character can be seen as a problem in one hand because the absence of the conception of urbanity causes our cities unable to form complete municipal entities: physical and cultural. Even so, it can be concluded that the uncertain structure of urban space as the sole basis of the formation of urbanity may be a simplification that can lead to a hurry conclusion. The improper use of glasses could make the potential of the spatial structure of Java not identified and explored.

Today many design concepts of cities in Indonesia imported western precedent, applying without sufficient understanding of the background of the concept. New concepts are often applied regardless of the background context of the formation of concepts, which has a different history of the formation of urban space from us. On the other hand we often fail to capture the potential of urban spaces that could have been the strength and distinctiveness of the design models of Indonesian cities because of the lack of understanding of the context of our own urban space creation. Superblock concept, for example, managed to lift visual and aesthetic quality

\footnotetext{
${ }^{31}$ Evers (2011: 187) explained that the absence of the urbanism conception, among others, was caused by the absence of a clear city structure and city institutions. Furthermore, he asserted his thesis that the process of urbanization of post-independence Indonesia cities ran without the concept of urbanism.

${ }^{32}$ Santoso (2009:21) took the example of Banten to describe this condition.
} 
of urban space instantly, but on the other hand removed the tissues of the Kampung kota or removed the old city area, any aspect of the exclusive benefits marginalized certain economic groups.

Efforts to understand the potential of Indonesian urban space must begin from the inside, a comprehensive understanding to our urban space. Study of the interaction between traditional urban space and colonial urban space in this paper is small part in the wider efforts to understand the unique character of Indonesian urban space. The step is a basic introduction of further step which can include the study of urban space preservation, design and development of unique potential of urban space, and so forth. The understanding of the unique character of urban space will lead to recognition of problems, potential and prospects of our urban space more comprehensively. That step is the basis for us to determine the concept that best fits to create a better urban space toward better city living quality, or briefly the concept of better space - better living.

\section{ACKNOWLEDGEMENT}

Material in this paper has been disseminated in the event of $1^{\text {st }}$ Biennale - International Conference on Indonesian Architecture and Planning, Gadjah Mada University, 2012.

\section{REFERENCES}

Adishakti, L.T. (1997). A Study on the Conservation Planning of Yogyakarta Historic-tourist City Based on Urban Space Heritage Conception. Dissertation. Graduate School of Global Environmental Engineering, Kyoto University. Japan.

Anonymos (-). Sejarah Gereja di Indonesia. (Arsip Gereja Protestan Indonesia Barat Kediri). Kediri.

Broadbent, G. (1990). Emerging Concepts in Urban Space Design. London : Van Nostrand Reinhold (International).

Crib, R. (2003). "Indisch" Identity and Decolonization. IIAS Newsletter no. 31 ed. Juli 2003 p.52. Amsterdam: Netherlands Institute for War Documentation (NIOD)

Evers, H.D. (2011). Urban Symbolism and the New Urbanism of Indonesia in Nas, P.J.M (ed). Cities Full of Symbols, A Theory of Urban Space and Culture. Leiden: Leiden University Press.

Gill, R.G. (1995). De Indische Stadt Op Java en Madura: een Morfologische Studie Van Haar Ontwikkeling. Doctoral Thesis in Technische Universiteit Delft. Delft: unpublished.
Handinoto. (1996). Perkembangan Kota dan Arsitektur Kolonial Belanda di Surabaya (1870-1940), LPPM Univeritas Kristen Petra, SurabayaAndi, Yogyakarta

Handinoto (2010). Arsitektur dan Kota-kota di Jawa pada Masa Kolonial. Yogyakarta: Graha Ilmu.

Heufel, C.vd (2005). 'De Huysbou', A reconstruction of an unfi nished treatise on architecture, town planning and civil engeering by Simon Stevin. Amsterdam: Royal Netherlands Academy of Arts and Sciences.

Ikaputra. (1995). A Study on the Contemporary Utilization of the Javanese Urban Heritage and its Effect on Hitoricity: An Attempt to Introduce the Contextual Adaptability into the Preservation of Historic Environment of Yogyakarta. Dissertation. Graduate School of Engineering, Osaka University. Japan.

Kostof, S. (1992). The City Assembled: The Elements of Urban Form Trough History, Thames and Hudson Ltd. London.

Krier, R. (1979). Urban Space. Academy Edition, London.

Lombard, D., (1996). Nusa Jawa Silang Budaya: Batas-batas Pembaratan. Gramedia Pustaka Utama, Jakarta.

Lombard, D., (1996). Nusa Jawa Silang Budaya: Jaringan Asia. Gramedia Pustaka Utama, Jakarta.

Lombard, D., (1996). Nusa Jawa Silang Budaya: Warisan Kerajaan-Kerajaan Konsentris. Gramedia Pustaka Utama, Jakarta.

Marihandono, D. (2007).Perubahan peran dan fungsi benteng dalam tata ruang kota downloaded from http://staff.ui.ac.id/internal/131124734/ material/ArtikelPerubahanFungsidanPeran Benteng.pdf March 20 ${ }^{\text {th }}, 2012$.

Muspriyanto, E. et.al (2006). Meretas Masa, Semarang Tempo Doeloe. Semarang: Terang Publishing

Nas, P.J.M. (1986). Introduction: A General View of the Indonesian Town in Nas, P.J.M (ed). The Indonesian City. Dordrecht: Foris Publication Holland.

Nas, P.J.M. (1986). The Early Indonesian Town: Rise and Decline of the City-State and its Capital in Nas, P.J.M (ed). The Indonesian City. Dordrecht: Foris Publication Holland.

Nas, P.J.M. and Boender, W. (2002). The Indonesian City in Urban Theory in Nas, P.J.M. (ed.) The Indonesian Town Revisited. Singapore: Institut of Southeast Asian Studies.

Passchier, C. (2009). Arsitektur Kolonial di Indonesia, Rujukan dan Perkembangan in Nas, P.J.M. (ed.) 
Masa Lalu dalam Masa Kini, Arsitektur di Indonesia. Jakarta: Penerbit PT Gramedia Pustaka Utama.

Santosa, R.B. (2000). Omah, Membaca Makna Rumah Jawa. Yogyakarta: Yayasan Bentang Budaya.

Santoso, J. (2006). [Menyiasati] Kota Tanpa Warga. Kepustakaan Populer Gramedia - Centropolis, Universitas Tarumanagara, Jakarta.

Santoso, J. (2008). Arsitektur - Kota Jawa, Kosmos, Kultur \& Kuasa, Centropolis, Universitas Tarumanagara, Jakarta.

Santoso, J. (2010). Proses Urbanisasi dalam Konteks Globalisasi: Surabaya, Beberapa Pemikiran Mengenai Kemandirian dan Keanekaragaman Kultural, Paper Seminar pada Seminar Nasional tentang Arsitektur (di) Kota "Hidup dan Berkehidupan di Surabaya", Jurusan Arsitektur, FTSP, Universitas Kristen Petra, Surabaya, 27 Mei.

Santoso, J. (2009). The Fifth Layer of Jakarta, Kontribusi untuk Internaional Architecture Biennale Rotterdam 2009. Jakarta: Magister Teknik Perencanaan - Centropolis Universitas Tarumanagara.

Siregar. S.A. (1990). Bandung, the Architecture of a City in Development: urban analysis of a regional capital as a contribution to the present debate on Indonesian urbanity and architectural identity. Doctoral Thesis in Katholieke Universiteit Leuven, Belgium. Leuven: Unpublished.

Supangkat, E. (2007). Salatiga, Sketsa Kota Lama. Salatiga: Griya Media.

Surjomihardjo, A. (2008). Kota Yogyakarta Tempo Doeloe, Sejarah Sosial 1880-1930. Jakarta: Komunitas Bambu.
Tim Penerbitan Buku Kenangan 75 tahun GKJ Sawokembar Gondokusuman Yogyakarta (1988). 75 tahun GKJ Sawokembar Gondokusuman Yogyakarta. Yogyakarta: Majelis Gereja Kristen Jawa Sawokembar Gondokusuman Yogyakarta

Weishaguna and Saodih, E. (-). Morfologi sebagai Pendekatan Memahami Kota. Bandung: Jurnal PWK Universitas Islam Bandung.

Widodo, J. (2009). Arsitektur Indonesia Modern, Transplantansi, Adaptasi, Akomodasi dan Hibridisasi in Nas, P.J.M. (ed.) Masa Lalu dalam Masa Kini, Arsitektur di Indonesia. Jakarta: Penerbit PT Gramedia Pustaka Utama.

Widodo, J. (2010). Research Methodologies in Architectural Studies/Urban Analysis. Materi Seminar Sehari - Research Methodologies. Program Doktor JUTAP FT UGM, Yogyakartaunpublished

Widodo, J. (2004). The Boat and The City, Chinese Diaspora and the Architecture of South East Asian Coastal Cities. Marshall Cavendish Academic, Singapore.

Wiryomartono, A.B.P. (1995). Seni Bangunan dan Seni Binakota di Indonesia; Kajian mengenai konsep, struktur, dan elemen fisik kota sejak perdadaban Hindu-Budha, Islam hingga sekarang. Gramedia Pustaka Utama, Jakarta.

Zahnd, M. (1999). Perancangan Kota Secara Terpadu, Teori Perancangan Kota dan Penerapannya. Yogyakarta: Penerbit Kanisius.

Zahnd, M. (2008). Model Baru Perancangan Kota yang Kontekstual, Kajian tentang kawasan tradisional di kota Semarang dan YogyakartaSuatu potensi perancangan kota yang efektif. Yogyakarta: Penerbit Kanisius. 